\title{
Article \\ Effects of Ridge Tillage and Straw Mulching on Cultivation the Fresh Faba Beans
}

\author{
Bo Li ${ }^{1,2}$, Xinyu Chen ${ }^{1}$, Xiaoxu Shi ${ }^{2}$, Jian Liu ${ }^{2}$, Yafeng Wei ${ }^{2, *}$ and Fei Xiong ${ }^{1, *}$ \\ 1 Jiangsu Key Laboratory of Crop Genetics and Physiology, College of Horticulture and Plant Protection, \\ Yangzhou University, Yangzhou 225009, China; libo1226520@163.com (B.L.); dx120190156@yzu.edu.cn (X.C.) \\ 2 Jiangsu Yanjiang Institute of Agricultural Sciences, Nantong 226541, China; 20182003@jaas.ac.cn (X.S.); \\ ntliuj@sina.com (J.L.) \\ * Correspondence: w-yafeng@163.com (Y.W.); feixiong@yzu.edu.cn (F.X.)
}

Citation: Li, B.; Chen, X.; Shi, X.; Liu, J.; Wei, Y.; Xiong, F. Effects of Ridge Tillage and Straw Mulching on Cultivation the Fresh Faba Beans. Agronomy 2021, 11, 1054 https://doi.org/10.3390/ agronomy11061054

Academic Editor: Marisol Berti

Received: 1 May 2021

Accepted: 21 May 2021

Published: 24 May 2021

Publisher's Note: MDPI stays neutral with regard to jurisdictional claims in published maps and institutional affiliations.

Copyright: (c) 2021 by the authors. Licensee MDPI, Basel, Switzerland. This article is an open access article distributed under the terms and conditions of the Creative Commons Attribution (CC BY) license (https:// creativecommons.org/licenses/by/ $4.0 /)$.

\begin{abstract}
Ridge tillage is an effective agronomic practice and a miniature precision agriculture; however, its effects on the growth of faba beans (Vicia faba L.) are poorly understood. This study aimed to determine the effect of ridge tillage and straw mulching on the root growth, nutrient accumulation and yield of faba beans. Field experiments were conducted during 2016 and 2017 cropping seasons and comprised four treatments: ridge tillage without any mulching (RT), flat tillage without any mulch (FT), flat tillage with rice straw mulched on the ridge tillage (FTRSM) and ridge tillage with rice straw mulched on the ridge tillage (RTRSM). The RT and RTRSM increased soil temperature and decreased soil humidity and improved soil total nitrogen, total phosphorus, available potassium and organic matter. RT and RTRSM increased the root length density, root surface area, root diameter and root activity of faba beans at flowering and harvest periods. The RT and RTRSM also increased the nitrogen, phosphorus, potassium absorption and the yield of faba beans. These results indicated that ridge tillage and straw mulching affect faba bean growth by improving soil moisture conditions and providing good air permeability and effective soil nutrition supply. This study provides a theoretical basis for the high yield cultivation improvement of faba beans.
\end{abstract}

Keywords: ridge tillage; faba bean; nutrient; growth; yield

\section{Introduction}

Faba beans have been cultivated for 800-1000 years and are an important winter crop in warm temperate and subtropical areas and an essential source of protein rich food in developing countries consumed as a vegetable [1], green or dried, fresh or canned [2,3]. The amount of cultivated faba beans worldwide was estimated to be 2.4 million hectares in 2016 and majority of the total global area of production is located in China, followed by Ethiopia and the European Union; however, the faba bean yield in China was lower than the world average yield [4]. Fresh faba beans have become one of the indispensable bean vegetable varieties in the market of southeast coast and Yangtze River basin in China and have unique roles of improving the multiple cropping index, enriching multiple compound and efficient planting types and increasing farmers' income and agricultural efficiency.

Faba beans are also grown for green manure and can substantially enhance the yields of cereals or other crops [5]. As a friendly former crop of rice, corn, potato and rapeseed, these beans play an important role in rotation or intercropping, especially in fertilizing the soil, protecting farmland ecological environment, reducing weight and agricultural non-point source pollution, increasing efficiency and improving the quality of agricultural products. In China, faba beans are autumn-sown after rice (Oryza sativa L.) or intercropped with cotton or maize in southern and western provinces [6]. During production, faba beans often have a low yield and seedling rate, rotting roots and weak seedlings.

Ridge tillage has attracted interest since the early 1980s. This practice effectively reduces soil erosion and increases crop yield [7-10]. The advantages of ridge tillage include improved 
soil fertility, water and pest management, deceased greenhouse gas emission [11], increased active soil depth [12-14], increased soil organic carbon (SOC) [15-17] and improved soil temperature and moisture environment for seed germination in early spring $[18,19]$. Four basic forms have been developed with the needs of crop practical production and the conditions of local climate (Figure 1) [20].

Returning the rice residue is an effective technique to conserve soil productivity [21], provides nutrients and increases chlorophyll and photosynthesis rate in the late growing period [22]. Returning straw to soil can improve soil structure, organic matter content and soil fertility and, thus, provide a good soil environment for crop growth [23]. Studies on the effect of ridge tillage and crop residues on faba bean grain development, specifically root morphology and nutritional element absorption, remain insufficient. In this work, the effect of ridge tillage and straw mulching on soil environment and the root morphology and nutritional element absorption of faba beans were investigated. This study lays a foundation for the high yield cultivation and quality improvement of faba beans and provides a solution to the problem of low yield and rotting roots in rice-faba bean rotation, which is of great importance to the popularization and application of rice-faba bean planting mode.
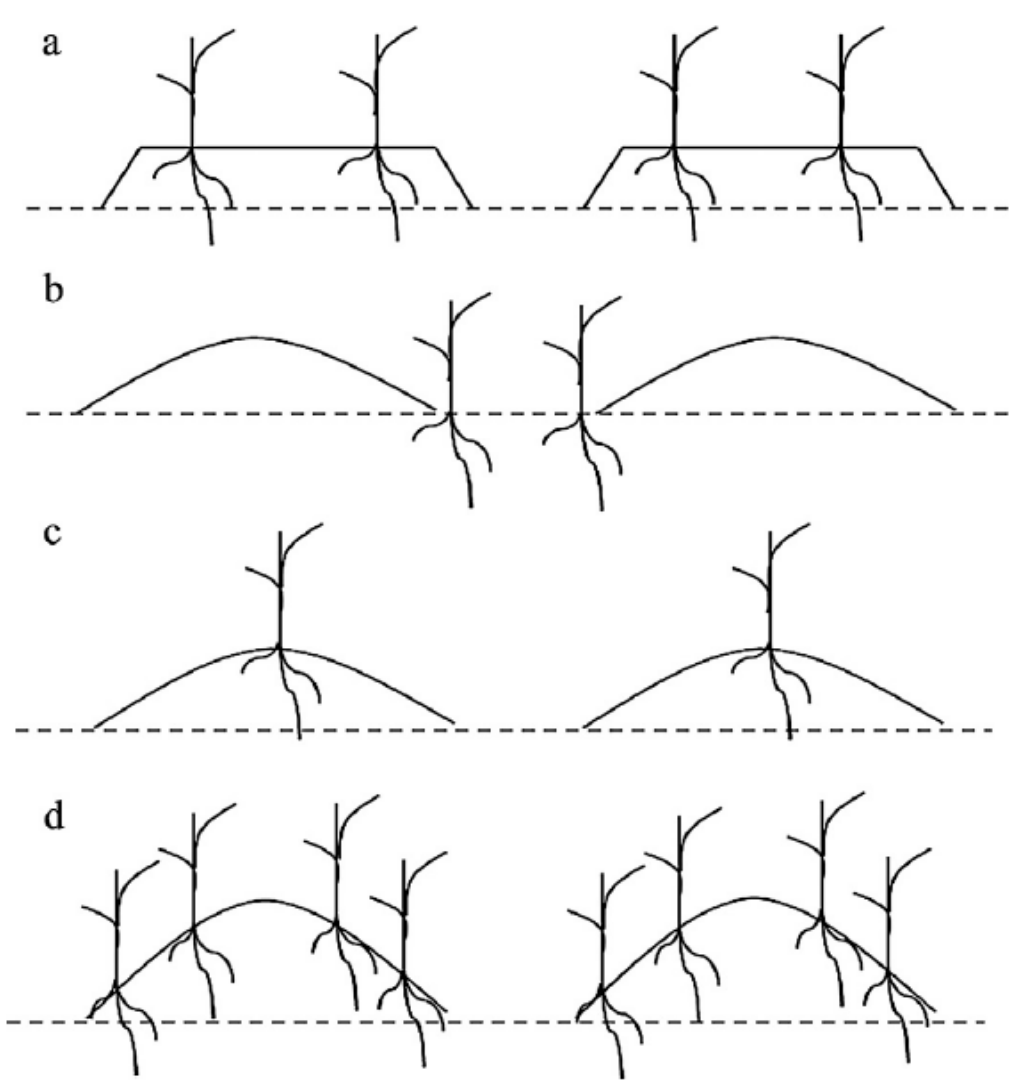

Figure 1. Four basic forms in the ridge tillage technology. (a-d) were bed (wide ridge) cultivation model, ridge and furrow planting of rainfall harvesting model, ridge mulching and planting of warming and water conservation model.

\section{Materials and Methods}

\subsection{Plant Material and Experimental Treatments}

The faba bean cultivar Tongcanxian 7 was provided by Jiangsu Yanjiang Institute of Agricultural Sciences (Nantong, China). A field experiment was conducted from October 2016 to June 2017 in the experimental field of Jiangsu Yanjiang Institute of Agricultural Sciences. The following four treatments were conducted: ridge tillage without any mulching (RT), ridge tillage with rice straw mulched on the surface of ridge (RTRSM), flat tillage 
without any mulch (FT) and flat tillage with rice straw mulch (FTRSM). In ridge tillage, the ridge height was $30 \mathrm{~cm}$ and the ridge width was $40 \mathrm{~cm}$ (Figure 2). The rice straw collected from the rice variety Nanjing 5055 was cut into $10 \mathrm{~cm}$ segments, which were planted on 15 May 2016 and mechanically harvested on 20 October 2016. The base fertilizer was applied with $375 \mathrm{~kg} \mathrm{ha}^{-1}$ compound fertilizer [CO(NH$\left.)_{2}: \mathrm{P}_{2} \mathrm{O}_{5}: \mathrm{K}_{2} \mathrm{O}=15: 15: 15\right]$ and $375 \mathrm{~kg} \mathrm{ha}^{-1}$ phosphorus fertilizer $\left(\mathrm{P}_{2} \mathrm{O}_{5}\right.$ content $\left.=12 \%\right)$. The planting density of faba beans was 90 thousand plants per hectare. The length of plot was $7.2 \mathrm{~m}$ and the width of plot was $2.7 \mathrm{~m}$. Each treatment was replicated three times.

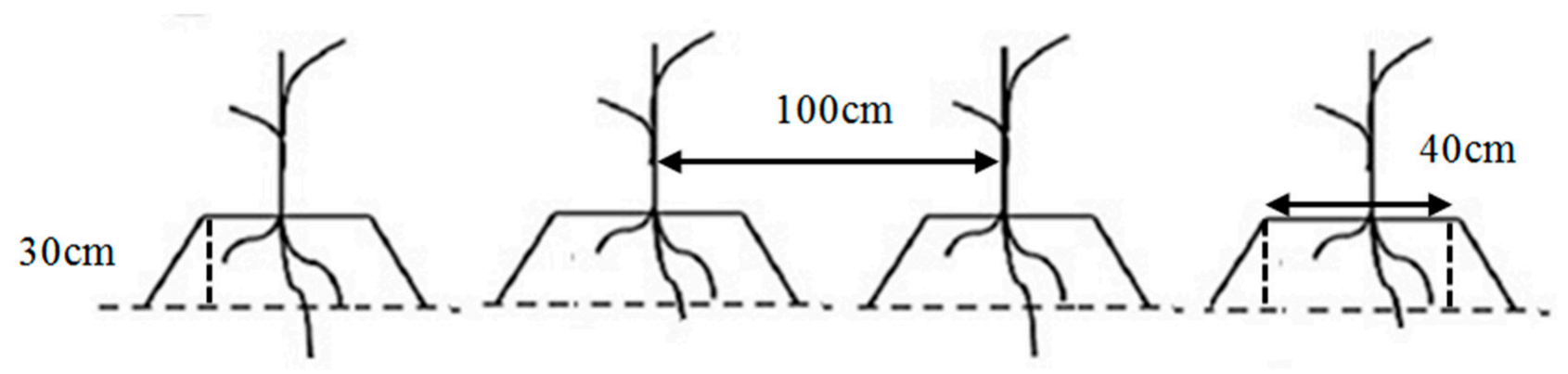

Figure 2. Schematic diagram of ridge tillage.

\subsection{Soil Parameter Determination}

Soil temperature and humidity recorder was used to record the soil temperature and humidity in the test plot. Soil samples were collected with a spade from the $0-15 \mathrm{~cm}$ depth to analyze total nitrogen, phosphorus, potassium and labile organic matter contents. Total nitrogen content was determined using the Kjeldhal method [24]. Soil samples were first digested with a mixed acid solution of $\mathrm{H}_{2} \mathrm{SO}_{4}$ and $\mathrm{HClO}_{4}$ before molybdenum blue method was applied with a spectrophotometer to measure the total phosphorus content [25]. Available potassium content of the soil was obtained by successive extractions with Mehlich-1 extractor $\left(\mathrm{HCl} 0.05 \mathrm{M}+\mathrm{H}_{2} \mathrm{SO}_{4} 0.0125 \mathrm{M}\right)$. This procedure consisted of conditioning $1.0 \mathrm{~g}$ of air-dried soil into Falcon tubes, in which $10 \mathrm{~cm}^{-3}$ of Mehlich-1 extractant solution was added. The samples were shaken for five minutes on a horizontal shaker and then centrifuged for five minutes at 2500 RPM. The supernatant was placed in plastic beaker and the potassium content in the extract was determined by flame emission spectrophotometer [26]. Labile organic matter content was analyzed using $\mathrm{KMnO}_{4}$ oxidation method [27].

\subsection{Root Morphology Observation}

Soil blocks of $15 \mathrm{~cm} \times 15 \mathrm{~cm} \times 15 \mathrm{~cm}$ were dug and washed with flowing water and the roots were then washed clean with agricultural compression sprayer. Root morphology was scanned using a root scanner (Microtek, scanmaker i800plus, made by Shanghai Zhongjing Technology Co., Ltd., Shanghai, China) and root length density, surface area and average diameter were analyzed by plant root analyzer system (LA-S, made by Hangzhou Wanshen Testing Technology Co., Ltd., Hangzhou, China). The number and dry weight of root nodule per plant were measured.

\subsection{Root Activity Determination}

Root activity was analyzed by the triphenyl tetrazolium chloride (TTC) method [28]. TTC is a chemical that is reduced by dehydrogenases, mainly succinate dehydrogenase, when added to a tissue. Dehydrogenase activity is regarded as an index of the root activity. In brief, $0.5 \mathrm{~g}$ of fresh root was immersed in $10 \mathrm{~cm}^{3}$ of equally mixed solution of $0.4 \%$ TTC and phosphate buffer and then kept in the dark at $37^{\circ} \mathrm{C}$ for $2 \mathrm{~h}$. Subsequently, $2 \mathrm{~cm}^{3}$ of $1 \mathrm{M} \mathrm{H}_{2} \mathrm{SO}_{4}$ was added to stop the reaction with the root. The root was dried with filter paper and then extracted with ethyl acetate. The red extractant was transferred into the volumetric flask to reach $10 \mathrm{~cm}^{3}$ by adding ethyl acetate. The absorbance of the extract at 
$485 \mathrm{~nm}$ was recorded. Root activity was expressed as TTC reduction intensity. Root activity $=$ amount of TTC reduction $(\mu \mathrm{g}) /$ fresh root weight $(\mathrm{g}) \times$ time $(\mathrm{h})$.

\subsection{Plant Dry Matter and Nutrient Substance Determination}

Six representative faba bean plants were taken from each plot at flowering and harvesting periods. The plants were divided into root, stem, leaf and seed. The samples were dried at $105^{\circ} \mathrm{C}$ for $30 \mathrm{~min}$ and then dried to constant weight at $80^{\circ} \mathrm{C}$. The dry weights of root, stem, leaf and seed were determined and the samples were then ground into powder to determine nitrogen, phosphorus and potassium contents. Nitrogen content was measured by micro-Kjeldahl digestion method, phosphorus content was analyzed colorimetrically by the vanado-molybdate method and potassium content was examined using a flame photometer [29]. The nutrient accumulation of different organs is equal to the nutrient content multiplied by the organ dry weight.

\subsection{Yield Characteristic Analysis}

Fresh faba bean pods were harvested and the yield in each plot was counted at harvesting period. Five representative faba bean plants were taken from each plot at harvesting period. Plant height, branch number of main stem, node number of main stem, pod weight per plant, pod number per plant and 100-seed weight per plant were statistically analyzed.

\subsection{Statistical Analysis}

Data were shown as the mean of triplicate determinations. One-way ANOVA and subsequent least-significant difference (LSD) test were performed using SPSS statistical procedure (SPSS Incorporated, Chicago, IL, USA). Differences at $0.01 \leq p<0.05$ were considered statistically significant.

\section{Results}

\subsection{Effect of Ridge Tillage and Straw Mulching on Soil Environment and Nutrient}

The soil temperature of RTRSM was the highest $\left(9.07^{\circ} \mathrm{C}\right)$ and was $2.45 \%$ higher than that of RT (Figure 3). The soil temperature of FTRSM was $0.47 \%$ higher than that of FT, that of RT was $2.91 \%$ higher than that of FT and that of RTRSM was $4.98 \%$ higher than that of FTRSM. This result indicates that ridge tillage and straw mulched help increase the soil temperature. The soil humidity of FTRSM was higher than that of RTRSM and that of RT was significantly reduced than that of FT. This finding indicates that ridge cover is helpful in reducing soil humidity.
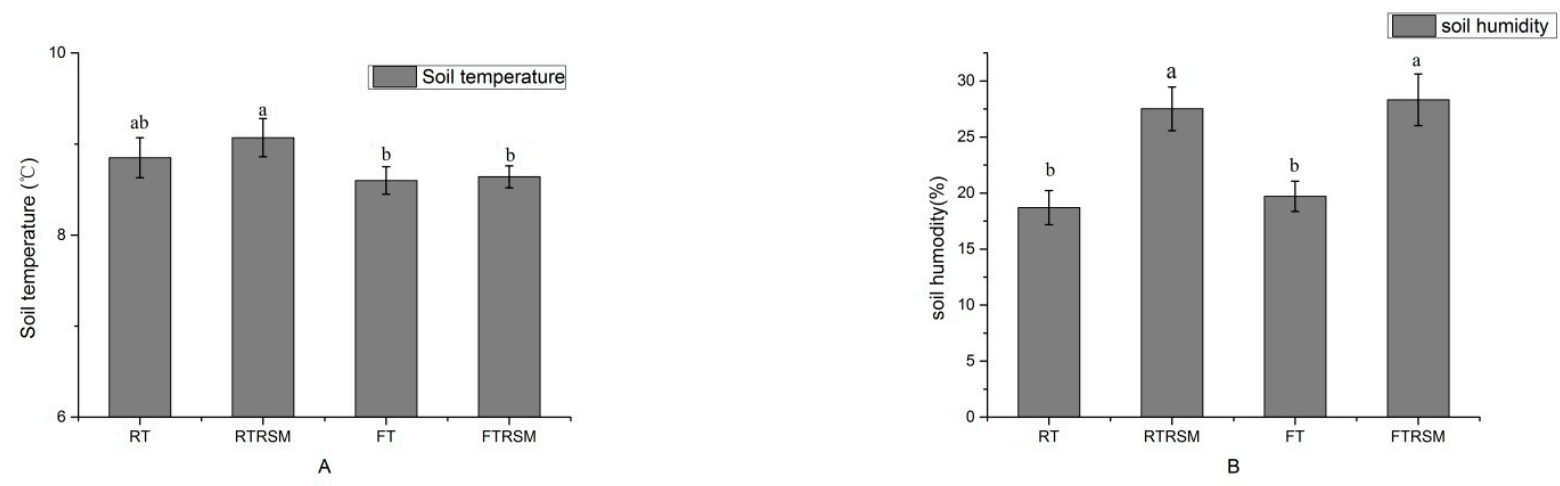

Figure 3. Soil temperature and soil humidity under different treatments. (A), soil temperature under different treatments. (B), soil humidity under different treatments. FT. flat tillage without any mulch; FTRSM, flat tillage with rice straw mulched; RT. ridge tillage without any mulching; RTRSM, ridge tillage with rice straw mulched. Different lowercase above histogram indicates significant difference between treatments. 
RT significantly improved the soil total nitrogen content compared with FT. Meanwhile, the soil total nitrogen, phosphorus, soluble potassium and organic matter contents under RTRSM were higher than those under RT. This tendency was consistent with the difference between FTRSM and FT (Table 1). These results indicated that ridge tillage and straw mulching improve the contents of nutrient and organic matter in soil.

Table 1. Total nitrogen, phosphorus, available potassium and labile organic matter contents of soil under different treatments.

\begin{tabular}{|c|c|c|c|c|}
\hline Treatment & Total Nitrogen $\left(\mathrm{g} \mathrm{kg}^{-1}\right)$ & Total Phosphorus $\left(\mathrm{g} \mathrm{kg}^{-1}\right)$ & $\begin{array}{l}\text { Available Potassium } \\
\qquad\left(\mathrm{mg} \mathrm{kg}^{-1}\right)\end{array}$ & $\begin{array}{l}\text { Labile Organic Matter } \\
\qquad\left(\mathrm{mg} \mathrm{kg}^{-1}\right)\end{array}$ \\
\hline RTRSM & $1.46^{\mathrm{a}}$ & $1.44^{\mathrm{a}}$ & $59.43^{a}$ & $19.42^{\mathrm{a}}$ \\
\hline $\mathrm{RT}$ & $1.23^{b}$ & $1.30^{\mathrm{a}}$ & $56.89^{a}$ & $15.58^{b}$ \\
\hline FT & $0.93^{c}$ & $1.35^{\mathrm{a}}$ & $56.71^{a}$ & $15.36^{b}$ \\
\hline FTRSM & $1.08^{\mathrm{c}}$ & $1.41^{\mathrm{a}}$ & $59.92^{a}$ & $19.39^{\mathrm{a}}$ \\
\hline
\end{tabular}

FT. flat tillage without any mulch; FTRSM, flat tillage with rice straw mulched; RT. ridge tillage without any mulching; RTRSM, ridge tillage with rice straw mulched. Different lowercase in the same column indicates significant difference between treatments.

\subsection{Effect of Ridge Tillage and Straw Mulching on the Root Development of Faba Beans}

Roots play an important role in absorption and metabolism [30]. The root length density, root surface area, root diameter and root activity of faba beans increased from flowering to harvesting period. The root length density and average diameter increased under RT compared with those under FT at flowering period, but no significant difference in root morphology was observed between RT and FT at harvesting period. Compared with RT, RTRSM significantly increased the surface area at flowering period and root length density, surface area and average diameter at harvesting period. Under FTRSM, root length density was higher at flowering period than at harvest; and root length density, surface area and average diameter were higher at harvesting period than under FT (Table 2). In addition, root activity was the highest under RTRSM at flowering period, followed by RT, FTRSM and FT (Figure 4). The results showed that ridge tillage and straw mulching promote the root growth and activity of faba beans.

Table 2. The root morphology of faba bean under different treatments at different periods.

\begin{tabular}{|c|c|c|c|c|c|c|}
\hline \multirow[b]{2}{*}{ Treatments } & \multicolumn{3}{|c|}{ Flowering Period } & \multicolumn{3}{|c|}{ Harvesting Period } \\
\hline & $\begin{array}{c}\text { Root Length } \\
\text { Density }\left(\mathrm{cm} \mathrm{cm}^{-3}\right)\end{array}$ & $\begin{array}{l}\text { Surface Area } \\
\left(\mathrm{cm}^{2} \mathrm{~cm}^{-3}\right)\end{array}$ & $\begin{array}{c}\text { Average } \\
\text { Diameter }(\mathrm{mm})\end{array}$ & $\begin{array}{c}\text { Root Length } \\
\text { Density }\left(\mathrm{cm} \mathrm{cm}^{-3}\right)\end{array}$ & $\begin{array}{l}\text { Surface Area } \\
\left(\mathrm{cm}^{2} \mathrm{~cm}^{-3}\right)\end{array}$ & $\begin{array}{c}\text { Average } \\
\text { Diameter }(\mathrm{mm})\end{array}$ \\
\hline RTRSM & $1.03^{\mathrm{a}}$ & $2.91^{\mathrm{a}}$ & $3.59^{a, b}$ & $1.7^{\mathrm{a}}$ & $3.82^{a}$ & $4.96^{\mathrm{a}}$ \\
\hline RT & $0.94^{\mathrm{a}}$ & $1.38^{\mathrm{b}}$ & $3.87^{\mathrm{a}}$ & $1.34^{b, c}$ & $2.04^{\mathrm{c}}$ & $4.68^{b}$ \\
\hline FT & $0.82^{b}$ & $1.17^{b}$ & $2.75^{b}$ & $1.22^{\mathrm{c}}$ & $1.98^{\mathrm{c}}$ & $4.71^{\mathrm{b}}$ \\
\hline FTRSM & $0.93^{\mathrm{a}}$ & $1.53^{b}$ & $3.62^{\mathrm{a}, \mathrm{b}}$ & $1.46^{\mathrm{b}}$ & $2.46^{\mathrm{b}}$ & $4.98^{\mathrm{a}}$ \\
\hline
\end{tabular}

Different lowercase in the same column indicate significant difference between treatments.

Compared with FT, RT significantly increased the number of root nodules at both flowering and harvesting periods and the dry weight of root nodules at flowering period. Meanwhile, the dry weight of root nodules under RTRSM was higher than that under RT at harvest period (Table 3). The results indicated that ridge tillage increases the number and dry weight of root nodules and straw mulching has minimal effect on the formation of root nodules. 


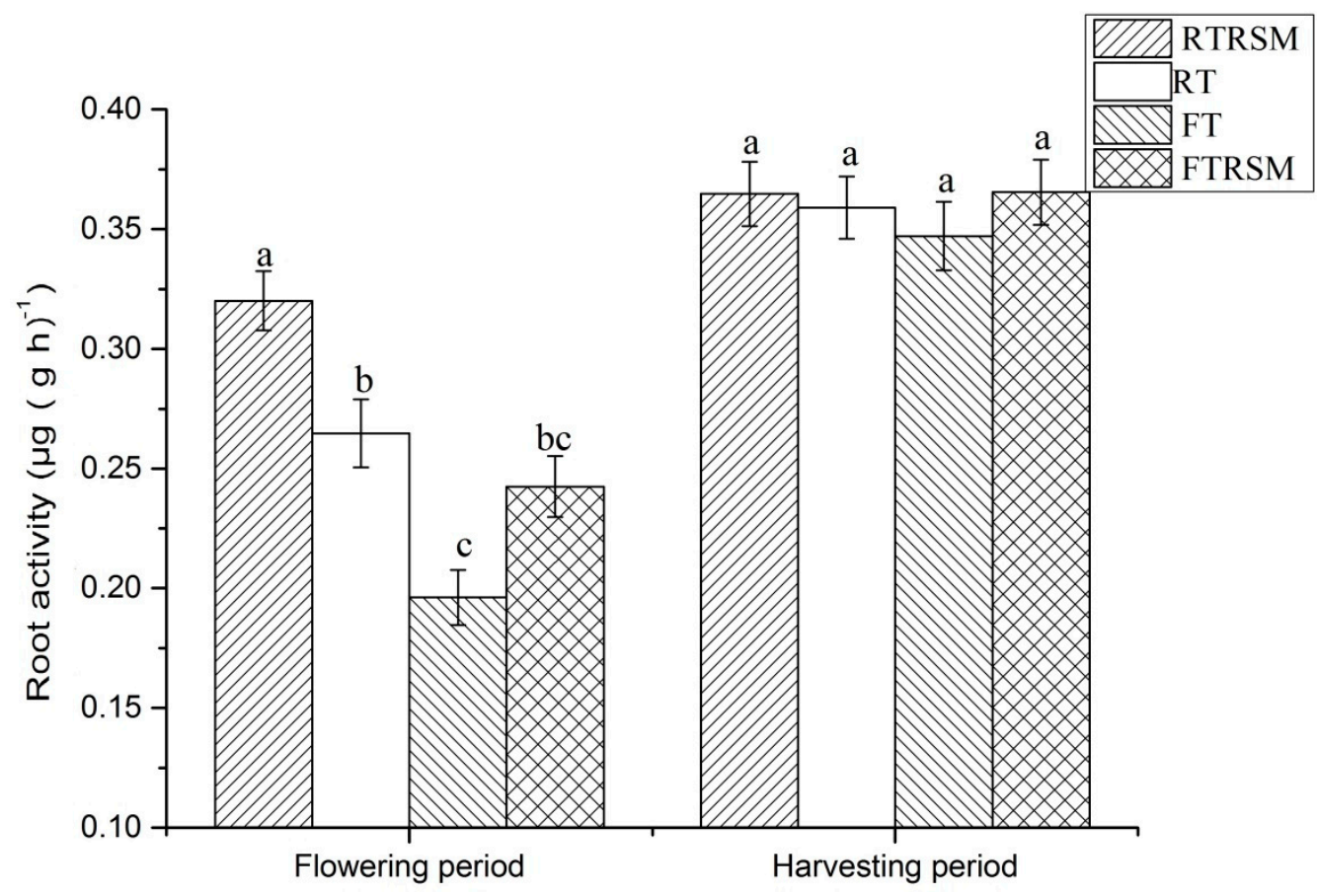

Figure 4. The root activity of faba bean under different treatments at different periods. FT. flat tillage without any mulch; FTRSM, flat tillage with rice straw mulched; RT. ridge tillage without any mulching; RTRSM, ridge tillage with rice straw mulched. Different lowercase above histogram indicates significant difference between treatments.

Table 3. The root nodules number and dry weight of faba bean under different treatments at different periods.

\begin{tabular}{ccccc}
\hline \multirow{2}{*}{ Treatment } & \multicolumn{2}{c}{ Root Nodules Number Per Plant } & \multicolumn{2}{c}{ Root Nodules Dry Weight Per Plant (g) } \\
\cline { 2 - 5 } & $\begin{array}{c}\text { Flowering } \\
\text { Period }\end{array}$ & $\begin{array}{c}\text { Harvesting } \\
\text { Period }\end{array}$ & Flowering Period & $\begin{array}{c}\text { Harvesting } \\
\text { Period }\end{array}$ \\
\hline RTRSM & $56^{\mathrm{a}}$ & $42.3^{\mathrm{a}}$ & $0.207^{\mathrm{a}}$ & $0.151^{\mathrm{a}}$ \\
RT & $54.5^{\mathrm{a}}$ & $41.2^{\mathrm{a}}$ & $0.195^{\mathrm{a}}$ & $0.135^{\mathrm{b}}$ \\
FT & $45.7^{\mathrm{b}}$ & $32.1^{\mathrm{b}}$ & $0.173^{\mathrm{b}}$ & $0.127^{\mathrm{b}, \mathrm{c}}$ \\
FTRSM & $48.9^{\mathrm{b}}$ & $34.5^{\mathrm{b}}$ & $0.185^{\mathrm{a}, \mathrm{b}}$ & $0.116^{\mathrm{c}}$ \\
\hline
\end{tabular}

FT. flat tillage without any mulch; FTRSM, flat tillage with rice straw mulched; RT. ridge tillage without any mulching; RTRSM, ridge tillage with rice straw mulched. Different lowercase in the same column indicates significant difference between treatments.

\subsection{Effect of Ridge Tillage and Straw Mulching on the Dry Matter and Nutrient Accumulation of} Faba Bean

At flowering period, the dry weights of roots, stems and leaves under RTRSM and RT were higher than those under FTRSM and FT. At harvesting period, the dry weights of roots, stems, leaves and seeds under RTRSM and RT were significantly increased compared with those under FTRSM and FT. Meanwhile, the dry matter accumulation in seed under RTRSM was higher than that under RT (Table 4). These results indicated that ridge tillage and straw mulching are beneficial to increase the dry matter accumulation of faba beans.

The nutrient accumulation in roots, stems, leaves and seeds was determined as shown in Table 5. For nitrogen, the accumulation in roots, stems and leaves under RTRSM and RT was higher than that under FTRSM and FT at flowering period. Meanwhile, the accumulation in roots, leaves and seeds under RTRSM and RT was higher than that under FTRSM and FT at harvesting period. Compared with RT, the nitrogen accumulation in the whole plant significantly increased under RTRSM at flowering period. RTRSM and RT increased the phosphorus accumulation in roots, stems, leaves and seeds compared with FTRSM and FT at both flowering and harvesting periods. The phosphorus accumulation 
in the whole plant under RTRSM and FTRSM was higher than that under RT and FT at flowering period. The potassium accumulation in roots, stems, leaves and seeds was the highest under RTRSM, followed by RT, FTM and FT at flowering and harvesting periods. The RTRSM significantly increased the potassium accumulation in the whole plant compared with RT at flowering period and FT at harvesting period. These results indicated that ridge tillage and straw mulching improve the accumulation of nitrogen, phosphorus and potassium in faba bean plants.

Table 4. The dry matter accumulation of faba bean in different organs under different treatments at different periods.

\begin{tabular}{|c|c|c|c|c|c|c|c|}
\hline \multirow[b]{2}{*}{ Treatment } & \multicolumn{3}{|c|}{ Flowering Period } & \multicolumn{4}{|c|}{ Harvesting Period } \\
\hline & $\begin{array}{c}\text { Root } \\
\text { (g Plant }^{-1} \text { ) }\end{array}$ & $\begin{array}{c}\text { Stem } \\
\left.\text { (g Plant }^{-1}\right)\end{array}$ & $\begin{array}{c}\text { Leaf } \\
{\left.\text { (g } \text { Plant }^{-1}\right)}^{-1}\end{array}$ & $\begin{array}{c}\text { Root } \\
\left.\text { (g Plant }^{-1}\right)\end{array}$ & $\begin{array}{c}\text { Stem } \\
\left.\text { (g Plant }^{-1}\right)\end{array}$ & $\begin{array}{c}\text { Leaf } \\
{\left.\text { (g } \text { Plant }^{-1}\right)}^{-1}\end{array}$ & $\begin{array}{c}\text { Seed } \\
\left.\text { (g Plant }^{-1}\right)\end{array}$ \\
\hline RTRSM & $5.68^{a}$ & $31.96^{\mathrm{a}}$ & $11.75^{\mathrm{a}}$ & $7.57^{\mathrm{a}}$ & $36.72^{a, b}$ & $15.24^{\mathrm{a}, \mathrm{b}}$ & $16.33^{b}$ \\
\hline $\mathrm{RT}$ & $5.57^{\mathrm{a}, \mathrm{b}}$ & $30.92^{a, b, c}$ & $11.24^{\mathrm{a}, \mathrm{b}}$ & $7.18^{a, b}$ & $38.86^{\mathrm{a}}$ & $16.75^{\mathrm{a}, \mathrm{b}}$ & $18.90^{\mathrm{a}}$ \\
\hline FT & $3.4^{\mathrm{c}}$ & $20.46^{c}$ & $7.56^{\mathrm{b}}$ & $5.4^{\mathrm{c}}$ & $28.86^{c}$ & $12.56^{\mathrm{b}}$ & $13.29^{c}$ \\
\hline FTRSM & $3.60^{c}$ & $25.62^{b, c}$ & $9.13^{\mathrm{a}, \mathrm{b}}$ & $5.60^{c}$ & $33.32^{b}$ & $13.13^{\mathrm{a}, \mathrm{b}}$ & $14.06^{\mathrm{c}}$ \\
\hline
\end{tabular}

FT. flat tillage without any mulch; FTRSM, flat tillage with rice straw mulched; RT. ridge tillage without any mulching; RTRSM, ridge tillage with rice straw mulched. Different lowercase in the same column indicates significant difference between treatments.

Table 5. Nitrogen, phosphorus and potassium accumulation of faba bean in different organs under different treatments at different periods.

\begin{tabular}{|c|c|c|c|c|c|c|c|c|c|c|}
\hline \multirow[b]{2}{*}{ Nutrient } & \multirow[b]{2}{*}{ Treatment } & \multicolumn{4}{|c|}{ Flowering Period } & \multicolumn{5}{|c|}{ Harvesting Period } \\
\hline & & $\begin{array}{c}\text { Root } \\
(\mathrm{mg} \\
\left.\text { Plant }^{-1}\right)\end{array}$ & $\begin{array}{c}\begin{array}{c}\text { Stem } \\
(\mathrm{mg}\end{array} \\
\left.\text { Plant }^{-1}\right)\end{array}$ & $\begin{array}{c}\begin{array}{c}\text { Leaf } \\
(\mathrm{mg}\end{array} \\
\left.\text { Plant }^{-1}\right)\end{array}$ & $\begin{array}{c}\text { Total } \\
(\mathrm{mg} \\
\left.\text { Plant }^{-1}\right)\end{array}$ & $\begin{array}{c}\begin{array}{c}\text { Root } \\
(\mathrm{mg}\end{array} \\
\left.\text { Plant }^{-1}\right)\end{array}$ & $\begin{array}{c}\text { Stem } \\
(\mathrm{mg} \\
\left.\text { Plant }^{-1}\right)\end{array}$ & $\begin{array}{c}\text { Leaf } \\
(\mathrm{mg} \\
\left.\text { Plant }^{-1}\right)\end{array}$ & $\begin{array}{c}\begin{array}{c}\text { Seed } \\
(\mathrm{mg}\end{array} \\
\left.\text { Plant }^{-1}\right)\end{array}$ & $\begin{array}{c}\text { Total } \\
(\mathrm{mg} \\
\left.\text { Plant }^{-1}\right)\end{array}$ \\
\hline \multirow{4}{*}{ Nitrogen } & RTRSM & $144.52^{\mathrm{a}}$ & $848.44^{a}$ & $425.92^{a}$ & $1418.88^{a}$ & $159.90^{\mathrm{a}}$ & $986.52^{a}$ & $522.26^{\mathrm{a}}$ & $729.08^{a}$ & $2397.76^{a}$ \\
\hline & RT & $115.07^{b}$ & $729.79^{b}$ & $383.27^{b}$ & $1228.13^{b}$ & $121.52^{b}$ & $904.78^{b, c}$ & $505.94^{a, b}$ & $695.23^{b}$ & $2227.47^{\mathrm{a}}$ \\
\hline & FT & $65.37^{c}$ & $681.22^{c}$ & $269.54^{\mathrm{d}}$ & $1016.13^{c}$ & $82.66^{\mathrm{d}}$ & $889.56^{c}$ & $454.84^{c}$ & $550.74^{c}$ & $1977.80^{b}$ \\
\hline & FTRSM & $75.94^{c}$ & $621.71^{c}$ & $328.92^{c}$ & $1026.57^{c}$ & $105.58^{c}$ & $833.44^{c}$ & $490.19^{b}$ & $585.27^{c}$ & $2014.48^{b}$ \\
\hline \multirow{4}{*}{ Phosphorus } & RTRSM & $21.55^{\mathrm{a}}$ & $135.92^{\mathrm{a}}$ & $44.64^{\mathrm{a}}$ & $202.12^{\mathrm{a}}$ & $26.18^{a}$ & $142.32^{\mathrm{a}}$ & $48.92^{\mathrm{a}}$ & $138.64^{a}$ & $356.06^{a}$ \\
\hline & RT & $17.91^{b}$ & $120.74^{b}$ & $36.63^{b}$ & $175.27^{b}$ & $25.45^{\mathrm{a}}$ & $123.02^{b}$ & $47.8^{a}$ & $118.26^{b}$ & $314.53^{a}$ \\
\hline & FT & $10.25^{c}$ & $80.65^{\mathrm{d}}$ & $23.92^{c}$ & $114.82^{\mathrm{d}}$ & $15.66^{b}$ & $74.71^{\mathrm{d}}$ & $37.93^{b}$ & $91.59^{c}$ & $219.89^{b}$ \\
\hline & FTRSM & $11.90^{c}$ & $105.00^{c}$ & $32.86^{b}$ & $149.76^{c}$ & $16.88^{b}$ & $89.91^{c}$ & $46.01^{\mathrm{a}}$ & $98.35^{c}$ & $251.15^{b}$ \\
\hline \multirow{4}{*}{ Potassium } & RTRSM & $55.45^{\mathrm{a}}$ & $672.51^{a}$ & $147.06^{\mathrm{a}}$ & $875.02^{a}$ & $56.68^{a}$ & $654.79^{a}$ & $199.60^{\mathrm{a}}$ & $217.28^{a}$ & $1128.35^{a}$ \\
\hline & RT & $47.05^{b}$ & $579.20^{\mathrm{b}}$ & $135.27^{b}$ & $761.52^{b}$ & $48.57^{b}$ & $571.00^{\mathrm{b}}$ & $173.99^{b}$ & $205.49^{a}$ & $999.05^{\mathrm{a}, \mathrm{b}}$ \\
\hline & FT & $36.07^{c}$ & $497.27^{c}$ & $95.05^{c}$ & $628.39^{c}$ & $44.55^{b}$ & $446.90^{c}$ & $139.21^{c}$ & $187.17^{b}$ & $817.83^{c}$ \\
\hline & FTRSM & $42.10^{b}$ & $538.02^{b}$ & $105.00^{c}$ & $685.12^{c}$ & $46.87^{b}$ & $527.57^{\mathrm{b}}$ & $146.77^{c}$ & $187.47^{\mathrm{b}}$ & $908.68^{b}$ \\
\hline
\end{tabular}

FT. flat tillage without any mulch; FTRSM, flat tillage with rice straw mulched; RT. ridge tillage without any mulching; RTRSM, ridge tillage with rice straw mulched. Different lowercase in the same column indicates significant difference between treatments.

\subsection{Effect of Ridge Tillage and Straw Mulching on the Yield Characteristics of Faba Beans}

The difference of plant height among the four treatments was not significant. The number of branches in main stem was the largest under RTRSM and the number of nodes in main stem was the largest under RT. RTRSM, RT and FTRSM significantly increased the weight of pod per plant compared with FT. The number of pods per plant under RTRSM and RT was higher than that under FTRSM and FT. Moreover, the 100-seed weight of faba beans under RTRSM was higher than that under RT, FTRSM and FT (Table 6). For the yield of faba beans, RTRSM produced the highest yield, followed by RT, FTRSM and FT. Meanwhile, the yield under FTRSM was significantly increased compared with that under FT (Figure 5). These results indicated that ridge tillage and straw mulching increase the yield of faba beans. 


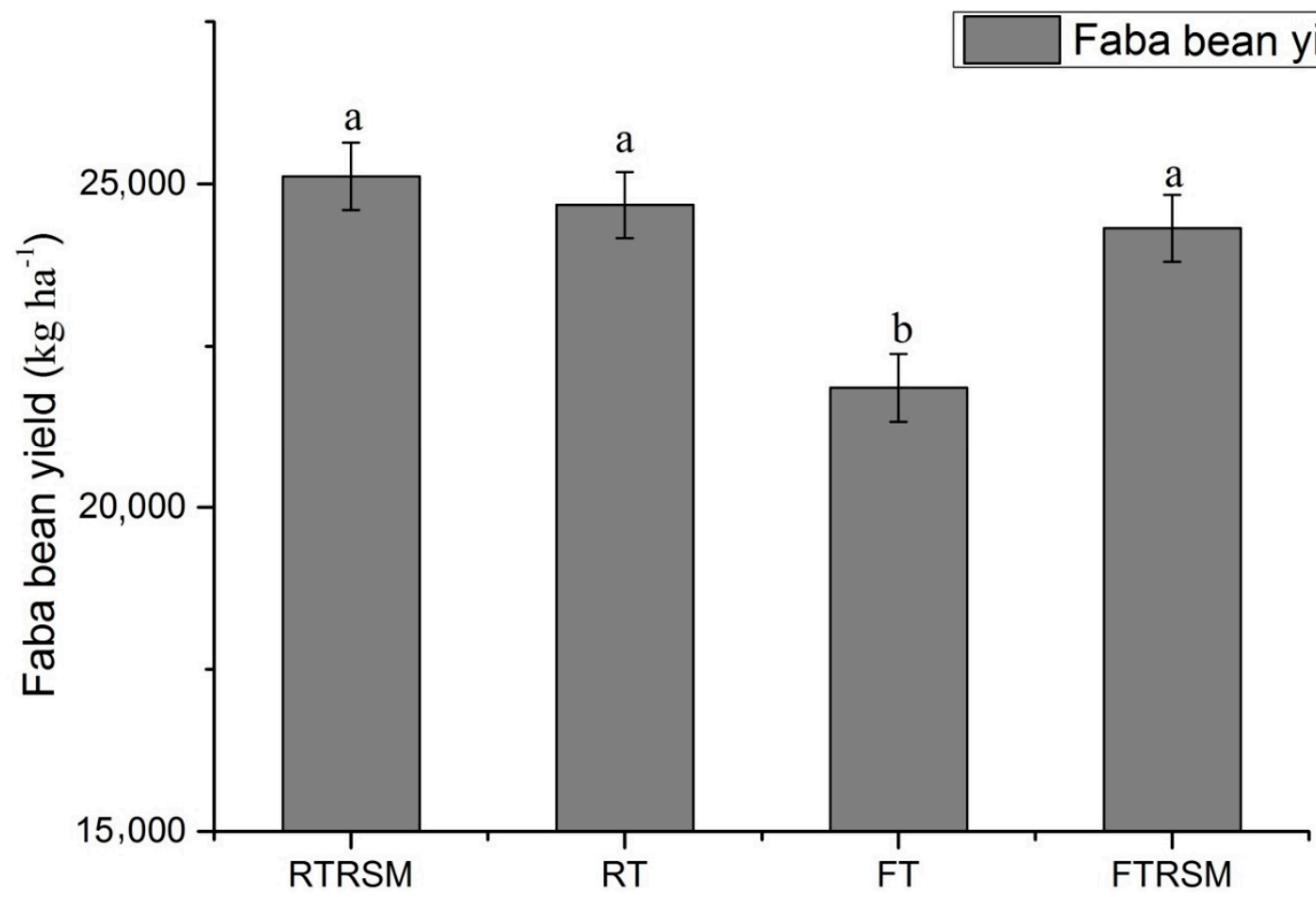

Figure 5. The yield of faba bean under different treatments. FT. flat tillage without any mulch; FTRSM, flat tillage with rice straw mulched; RT. ridge tillage without any mulching; RTRSM, ridge tillage with rice straw mulched. Different lowercase above histogram indicates significant difference between treatments.

Table 6. The agronomic characteristics of faba bean under different treatments at harvesting period.

\begin{tabular}{ccccccc}
\hline Treatment & $\begin{array}{c}\text { Plant Height } \\
(\mathbf{c m})\end{array}$ & $\begin{array}{c}\text { Branches } \\
\text { Number of } \\
\text { Main Stem }\end{array}$ & $\begin{array}{c}\text { Nodes Number } \\
\text { of Main Stem }\end{array}$ & $\begin{array}{c}\text { Pod Weight Per } \\
\text { Plant (g) }\end{array}$ & $\begin{array}{c}\text { Pods Number } \\
\text { Per Plant }\end{array}$ & $\begin{array}{c}\text { 100-Seeds } \\
\text { Weight (g) }\end{array}$ \\
\hline RTRSM & $111.17^{\mathrm{a}}$ & $5.67^{\mathrm{a}}$ & $15.50^{\mathrm{b}}$ & $283.04^{\mathrm{a}}$ & $13.25^{\mathrm{a}}$ & $386.9^{\mathrm{a}}$ \\
RT & $108.33^{\mathrm{a}}$ & $5.17^{\mathrm{b}, \mathrm{c}}$ & $17.67^{\mathrm{a}}$ & $281.18^{\mathrm{a}}$ & $13.17^{\mathrm{a}}$ & $375.55^{\mathrm{b}, \mathrm{c}}$ \\
FT & $112.83^{\mathrm{a}}$ & $5.50^{\mathrm{a}, \mathrm{b}}$ & $13.83^{\mathrm{c}}$ & $241.15^{\mathrm{b}}$ & $11.58^{\mathrm{b}}$ & $369.7^{\mathrm{c}}$ \\
FTRSM & $110.83^{\mathrm{a}}$ & $5.63^{\mathrm{a}}$ & $15.33^{\mathrm{b}}$ & $272.31^{\mathrm{a}}$ & $11.92^{\mathrm{a}, \mathrm{b}}$ & $381.85^{\mathrm{b}}$ \\
\hline
\end{tabular}

FT. flat tillage without any mulch; FTRSM, flat tillage with rice straw mulched; RT. ridge tillage without any mulching; RTRSM, ridge tillage with rice straw mulched. Different lowercase in the same column indicates significant difference between treatments.

\section{Discussion}

In this study, ridge tillage and straw mulching increased the soil temperature and decreased the soil humidity. He et al. [19] reported that relative to conventional tillage, ridge tillage significantly $(p<0.05)$ increases the mean soil temperature to $0.10 \mathrm{~m}$ depth by $0.7-2.48^{\circ} \mathrm{C}$ in the cold season during the spring maize growing stage. Compared with traditional ploughing, ridge tillage with straw cover increases soil temperature at $0.10 \mathrm{~m}$ depth by $1.08^{\circ} \mathrm{C}$ in April [31]. Yang et al. reported that ridge tillage generally enhances soil temperature, water content and crop development in Northeast China [32]. The use of ridgefurrow and plastic-mulching tillage can significantly increase the soil temperature [33]. Similar results were reported by Abu-Hamdeh et al. [34]. Radke [35] reported that the application of ridge tillage with residue cover could increase soil temperature due to the change in micro-topography. Ridge tillage increases the area of sunlight absorbed by the soil, thus increasing the soil temperature. However, our results show that ridge and ridge cover straw decrease soil moisture mainly due to the reduction of rain falling into the soil. The study of ridge and straw mulching to improve soil moisture is a long-term result of reducing soil moisture evaporation. 
The root length density, root surface area, root diameter and root activity under ridging tillage with rice straw mulched were higher than those under flat tillage. Ridge tillage induces the development of more functional nodal roots compared with no tillage and increases the root length density and surface area of rice [36]. Ridge covered with different mulches materials substantially enhances the rooting systems on the top $50 \mathrm{~cm}$ soil profile [37]. Studies in Canada and Australia have also indicated that the root diameter, root length density and root dry weight in legumes and cereals crops are positively correlated to soil water availability [38]. Ridge tillage improves the root growth and lateral root proliferation of corn, during a hot, dry growing season and affects root penetration and distribution $[39,40]$. Ren et al. reported that ridge tillage could promote plant root growth and development, total root biomass and volume, length and superficial area increase by 14-20\%, 14-34\%, 9-11\% and 14-15\%, respectively [41]. A remarkable increase in total root biomass and volume, absorption capacity and ratio of root and shoot was also observed and these effects lay the foundation for acquiring a high yield [42,43]. Qian et al. reported that under ridge tillage, the total absorption area, active absorption area and ratio of root and shoot increase by approximately $21 \%, 10-17 \%$ and $11-40 \%$, respectively [43]. Quan et al. stated that ridge tillage increases the total root biomass per plant by $39-110 \%$ compared with FT [44]. Ridge and ridge cover straw also promote root growth and development by providing good soil temperature and moisture.

In this study, ridge tillage increased the nitrogen, phosphorus and potassium absorption of the roots, stems and leaves of faba bean compared with flat tillage. This practice increases the leaf nitrogen, phosphorus and potassium of cocoyam compared with conventional tillage [45]. Compared with conventional flat tillage, ridge tillage substantially increases the accumulation of nitrogen, phosphorus and potassium in the stems and leaves of rice during heading and the accumulation rate of nitrogen, phosphorus and potassium, indicating that ridge tillage could increase the absorption, distribution and accumulation of nitrogen, phosphorus and potassium in the critical period of nutrient accumulation [46]. Ridges enhance the amount of nutrient uptake in the winter wheat/summer maize rotation system [47]. In this work, RT and RTRSM provided good soil temperature and moisture and promoted the nutrient absorption of faba beans. Liu et al. reported that a long-term ridge tillage treatment can stimulate inorganic nitrogen retention capacity and, thus, provides great capacity to supply available nitrogen for uptake by crop plants [48]. Ridge tillage can establish soil functional zones with distinct nitrogen profiles and the relocation of potentially mineralizable nitrogen in-row may increase the spatial efficiency of nitrogen provision relative to conventional tillage [49].

In this study, RTRSM and RT improved soil total nitrogen, total phosphorus, soluble potassium and organic matter compared with FT. Ridge tillage substantially increases total nitrogen, soil microbial biomass nitrogen and soil urease activity in soil aggregates [50]. Ridge tillage variation benefits soil microbial growth, accelerates the decomposition of soil organic matter, promotes the release and absorption of available nutrients and enhances nutrient utilization efficiency [51]. Doraiswamy et al. suggested that soil erosion is controlled and soil carbon sequestration is enhanced with a ridge tillage system [52]. Ridge tillage decreasing soil erosion may be the main reason the higher soil nutrient than that in flat tillage [53]. Straw mulch treatment improves soil total nitrogen, total phosphorus, soluble potassium and organic matter compared with no straw mulch treatment possibly due to the returned crop straw increasing the nitrogen content and activity of urease, phosphatase and invertase in the soil [54].

The yield of RTRSM was increased significantly compared with that of FT. The 3-year average maize yield for ridge tillage was $9.9 \%$ higher than that for CT [19]. Li et al. reported that under furrow-ridge mulching cultivation conditions, the grain yield of winter wheat increases by $16-44 \%$ [55]. Compared with flat tillage, ridge tillage increases the grain yield of potatoes, summer soybean and soybean by $75-86 \%, 13-21 \%$ and $25 \%$, respectively [56-58]. Tisdall and Hodgson reviewed ridge tillage practice in Australia and stated its successful application, mainly for vegetables or irrigated crops grown on poorly drained alfisols and 
vertisols [59]. The better yields from crops grown on ridges/furrow compared with those grown on flat land were attributed mainly to the improved soil moisture conditions, good air permeability and effective soil nutrition supply [30].

\section{Conclusions}

Under RT and RTRSM, the temperature of soil increased, but soil humidity decreased. Both treatments improved soil total nitrogen, phosphorus, available potassium and organic matter content. Ridge tillage and straw mulching changed the soil environment and affected the root growth and nutrient accumulation of faba beans. RT and RTRSM increased the root length density, root surface area, root diameter, root activity and the nitrogen, phosphorus and potassium absorption of roots, stems and leaves of faba beans at flowering and harvest periods. The yield of faba beans was the highest under RTRSM, followed by RT, FTRSM and FT. These results indicated that ridge tillage and straw mulching affect faba bean growth by improving soil moisture conditions and providing good air permeability and effective soil nutrition supply.

Author Contributions: F.X. and Y.W. designed the experiments. F.X. guided the research. B.L., X.S. and X.C. performed the experiments, analyzed the data, and wrote the manuscript. X.C., software; B.L., X.S. and X.C, formal analysis; Y.W., resources; B.L., writing-original draft preparation; X.S., Investigation; J.L., F.X. and Y.W., methodology; B.L. and X.C., writing-review and editing; B.L., visualization; J.L., supervision; F.X., project. All authors have read and agreed to the published version of the manuscript.

Funding: This study was funded by the National Key Research and Development Program of China (2016YFD030020904) and Jiangsu Province Agricultural Independent Innovation Fund Project [CX (18) 2019].

Institutional Review Board Statement: Not applicable.

Informed Consent Statement: Not applicable.

Data Availability Statement: The data presented in this study are available on request from the corresponding author.

Conflicts of Interest: The authors declare no conflict of interest.

\section{References}

1. Zohary, D.; Hopf, M. Domestication of plants in the Old World. Oxford Univ. 2000, 3, 316. [CrossRef]

2. Bond, D.A.; Lawes, G.C.; Saxena, M.C.; Stephens, J.S. Faba bean (Vicia faba L.). In Grain Legume Crops; Summerfield, R.J., Roberts, E.H., Eds.; William Collins Sons Co.: London, UK, 1985; pp. 199-265. [CrossRef]

3. Duke, J.A. Handbook of Legumes of World Economic Importance; Plenum Press: New York, NY, USA, 1981; pp. 199-265. [CrossRef]

4. FAOSTAT. 2008. Available online: http://faostat.fao.org/site/567/default.aspx\#ancor (accessed on 5 May 2009).

5. Wani, S.P.; McGill, W.B.; Haugenkozyra, K.L.; Robertson, J.A.; Thurston, J.J. Improved soil quality and barley yields with faba-beans, manure, forages and crop rotation on a gray luvisol. Can. J. Soil Sci. 1994, 74, 75-84. [CrossRef]

6. Zhang, F.; Shen, J.; Li, L.; Liu, X. An overview of rhizosphere processes related with plant nutrition in major cropping systems in China. Plant Soil 2004, 260, 89-99. [CrossRef]

7. Barton, A.P.; Fullen, M.A.; Mitchell, D.J.; Hocking, T.J.; Liu, L.; Bo, Z.W.; Zheng, Y.; Xia, Z.Y. Effects of soil conservation measures on erosion rates and crop productivity on subtropical Ultisols in Yunnan Province, China. Agric. Ecosyst. Environ. 2004, 104, 343-357. [CrossRef]

8. Quinton, J.N.; Catt, J.A. The effects of minimal tillage and contour cultivation on surface runoff, soil loss and crop yield in the long-term Woburn Erosion Reference Experiment on sandy soil at Woburn, England. Soil Use Manag. 2004, 20, 343-349. [CrossRef]

9. Shi, Z.H.; Cai, C.F.; Ding, S.W.; Wang, T.W.; Chow, T.L. Soil conservation planning at the small watershed level using RUSLE with GIS: A case study in the Three Gorge Area of China. Catena 2004, 55, 33-48. [CrossRef]

10. Stevens, C.J.; Quinton, J.N.; Bailey, A.P.; Deasy, C.; Silgram, M.; Jackson, D.R. The effects of minimal tillage, contour cultivation and in-field vegetative barriers on soil erosion and phosphorus loss. Soil Tillage Res. 2009, 106, 145-151. [CrossRef]

11. Patino-Zuniga, L.; Ceja-Navarro, J.A.; Govaerts, B.; Luna-Guido, M.; Sayre, K.D.; Den-dooven, L. The effect of different tillage and residue management practices on soil characteristics, inorganic $\mathrm{N}$ dynamics and emissions of $\mathrm{N}_{2} \mathrm{O}, \mathrm{CO}_{2}$ and $\mathrm{CH}_{4}$ in the central highlands of Mexico: A laboratory study. Plant Soil 2009, 314, 231-241. [CrossRef]

12. Lal, R. Ridge-tillage. Soil Till. Res. 1990, 18, 107-111. [CrossRef] 
13. Gaynor, J.D.; Findlay, W.I. Soil and phosphorus loss from conservation and conventional tillage in corn production. J. Environ. Qual. 1995, 24, 734-741. [CrossRef]

14. Pikul, J.L., Jr.; Carpenter-Boggs, L.; Vigil, M.; Schumacher, T.E.; Lindstrom, M.J.; Riedell, W.E. Crop yield and soil condition under ridge and chisel-plow tillage in the northern Corn Belt, USA. Soil Till. Res. 2001, 60, 21-33. [CrossRef]

15. Gao, M.; Luo, Y.J.; Wang, Z.F.; Tang, X.H.; Wei, C.F. Effect of tillage system on distribution of aggregates and organic carbon in a hydragric anthrosol project. Pedosphere 2008, 18, 574-581. [CrossRef]

16. Doumbia, M.; Jarju, A.; Sène, M.; Traoré, K.; Yost, R.; Kablan, R.; Brannan, K.; Berthe, A.; Yamoah, C.; Querido, A.; et al. Sequestration of organic carbon in West African soils by Ame'nagement en Courbes de Niveau. Agron. Sustain. Dev. 2009, 29, 267-275. [CrossRef]

17. Shao, J.A.; Li, Y.B.; Wei, C.F.; Xie, D.T. Effects of land management practices on labile organic carbon fractions in rice cultivation. Chin. Geogr. Sci. 2009, 19, 241-248. [CrossRef]

18. Stone, J.A.; Vyn, T.J.; Clarke, N.D. Ridge tillage for corn and soybean production on clay and clay-loam soils in southwestern Ontario-A review. Soil Till. Res. 1990, 18, 219-230. [CrossRef]

19. He, J.; Li, H.; Kuhn, N.J.; Wang, Q.; Zhang, X. Effect of ridge tillage, no-tillage, and conventional tillage on soil temperature, water use, and crop performance in cold and semi-arid areas in Northeast China. Soil Res. 2010, 48, 737-744. [CrossRef]

20. Zheng, H.; Huang, H.; Liu, J.; Yao, L.; He, H. Recent progress and prospects in the development of ridge tillage cultivation technology in China. Soil Till. Res. 2014, 142, 1-7. [CrossRef]

21. Shen, M.X.; Yang, L.Z.; Yao, Y.M. Long-term effects of fertilizer managements on crop yields and organic carbon storage of a typical rice-wheat agroecosystem of China. Biol. Fertil. Soils 2007, 44, 187-200. [CrossRef]

22. Xu, Y.Z.; Nie, L.X.; Buresh, R.J.; Huang, J.L.; Cui, K.H.; Xu, B.; Gong, W.H.; Peng, S.B. Agronomic performance of late-season rice under different tillage, straw, and nitrogen management. Field Crops Res. 2010, 115, 79-84. [CrossRef]

23. Ling, Y.; Zhang, Z.; Cao, X.; Zhu, S.; Xuan, Z.; Wu, L. Responses of rice production, milled rice quality and soil properties to various nitrogen inputs and rice straw incorporation under continuous plastic film mulching cultivation. Field Crops Res. 2014, 155, 164-171. [CrossRef]

24. Corralfernández, R.; Parrasalcántara, L.; Lozanogarcía, B. Stratification ratio of soil organic c, $\mathrm{n}$ and c:n in mediterranean evergreen oak woodland with conventional and organic tillage. Agric. Ecosyst. Environ. 2013, 164, 252-259. [CrossRef]

25. Institute of Soil Science, Chinese Academy of Sciences (ISSCAS). Physical and Chemical Analysis Methods of Soils; Shanghai Science Technology Press: Shanghai, China, 1978. (In Chinese)

26. Almeida, T.F.; Carvalho, J.K.; Reid, E.; Martins, A.P.; Bissani, C.A.; Bortoluzzi, E.C.; Brunetto, G.; Anghinoni, I.; de Faccio Carvalho, P.C.; Tiecher, T. Forms and balance of soil potassium from a long-term integrated crop-livestock system in a subtropical Oxisol. Soil Till. Res. 2020, 207, 104864. [CrossRef]

27. Lefroy, R.D.B.; Blair, G.J.; Strong, W.M. Changes in soil organic matter with cropping as measured by organic carbon fractions and 13C natural isotope abundance. Plant Soil 1993, 155-156, 399-402. [CrossRef]

28. Wang, X.K.; Zhang, W.H.; Hao, Z.B.; Li, X.R.; Zhang, Y.Q.; Wang, S.M. Principles and Techniques of Plant Physiological Biochemical Experiment; Higher Education Press: Beijing, China, 2006; pp. 118-119. (In Chinese)

29. AOAC. Official Methods of Analysis of the Association of Official Analytical Chemists International, 16th ed.; AOAC International: Arlington, VA, USA, 1997; Volume 972, p. 43. [CrossRef]

30. Marschner, H.; Kirkby, E.A.; Cakmak, I. Effect of mineral nutritional status on shoot-root partitioning of photo assimilates and cycling of mineral nutrients. J. Exp. Bot. 1996, 47, 1225-1263. [CrossRef] [PubMed]

31. Wang, Q.J.; Li, H.W.; Xu, D.J.; Liu, A.D.; Zhang, X.D. Study on the technology of the corn no-till planting of one big ridge two rows. Agric. Res. Arid Areas 2007, 2, 17-20. (In Chinese) [CrossRef]

32. Yang, H.B.; Yan, L.; Xu, C.Z.; Wang, D.M.; Wang, F.H. The effect of wheat ridge tillage on soil temperature at different layer in day and night. Shandong Agric. Sci. 2005, 6, 28-30. (In Chinese) [CrossRef]

33. Zhou, L.; Jin, S.; Liu, C. Ridge-furrow and plastic-mulching tillage enhances maize-soil interactions: Opportunities and challenges in a semiarid agroecosystem. Field Crops Res. 2012, 126, 181-188. [CrossRef]

34. Abu-Hamdeh, N.H. Effects of tillage treatments on soil thermal conductivity for some Jordanian clay loam and loam soils. Soil Till. Res. 2000, 56, 145-151. [CrossRef]

35. Radke, J.K. Managing Early Season Soil Temperatures in the Northern Corn Belt Using Configured Soil Surfaces and Mulches1. Soil Sci. Soc. Am. J. 1982, 46, 1067-1071. [CrossRef]

36. Thomas, A.L.; Kaspar, T.C. Maize Nodal Root Response to Soil Ridging and Three Tillage Systems. Agron. J. 1995, 87, 853-858. [CrossRef]

37. Jia, Q.; Chen, K.; Chen, Y. Mulch covered ridges affect grain yield of maize through regulating root growth and root-bleeding sap under simulated rainfall conditions. Soil Till. Res. 2017, 175, 101-111. [CrossRef]

38. Liu, Y.; Tao, Y.; Wang, K.Y.; Zhang, G.S.; Liu, D.B.; Xiong, G.Y.; Chen, F. Runoff and nutrient losses in citrus orchards on sloping land subjected to different surface mulching practices in the Danjiangkou Reservoir area of China. Agric. Water Manag. 2012, 110, 34-40. [CrossRef]

39. Riedell, W.E.; Gustin, R.D.; Beck, D.L.; Hanson, D.G. western corn rootwormdamage: Effect of tillage on plant response and grain yield. Crop Sci. 1991, 31, 1293-1297. [CrossRef] 
40. Materechera, S.A.; Mioza-Banda, H.R. Soil penetration resistance, root growthand yield of maize as influenced by tillage system on ridges in Malawi. Soil Till. Res. 1997, 41, 13-24. [CrossRef]

41. Ren, X.L.; Jia, Z.K.; Chen, X.L.; Han, J.; Han, Q.F. Effect of ridge and furrow plantin g of rainfall harvesting on soil available nutrient distribution and root growth of summer corn under simulated rainfall conditions. Trans. CSAE 2007, 23, 94-99. (In Chinese)

42. Zhang, X.F.; Wang, D.Y.; Qu, Y.Y.; Li, H. Morphological and physiological characteristics of raised bed-cultivated rice. Acta Agron. Sin. 2005, 31, 742-748. (In Chinese) [CrossRef]

43. Qian, Y.D.; Li, J.F.; Zheng, G.P.; Lu, Y.D.; Guo, X.H.; Sun, C.Y. Effect of ridge cultivation on root growth of rice in cold region. Chin. J. Rice Sci. 2005, 19, 238-242. (In Chinese) [CrossRef]

44. Quan, M.H.; Hu, A.S.; Ou, L.J.; Hu, D.Y.; Li, B.H. Effects of tillage mode on characteristics of photosynthesis and root growth of rice. Hybrid Rice 2012, 27, 71-75. (In Chinese) [CrossRef]

45. Agbede, T.M. Nutrient availability and cocoyam yield under different tillage practices. Soil Till. Res. 2008, 99, 49-57. [CrossRef]

46. Wan, Q.H.; Li-Hua, M.A.; Jiang, X.J. Root characteristics and accumulation of nitrogen, phosphorus, and potassium in rice plants cultivated under three different systems. Acta Pratacult. Sin. 2019, 28, 44-52. (In Chinese)

47. Ma, L.; Li, C.H.; Zhao, Z.J.; Zhang, X.L. Nutrients utilization of integrative ridge planting system of winter wheat and summer maize. Plant Nutr. Fertil. Sci. 2011, 17, 500-505. (In Chinese) [CrossRef]

48. Liu, S.; Zhang, X.; Liang, A.; Zhang, J.; Müller, C.; Cai, Z. Ridge tillage is likely better than no tillage for 14-year field experiment in black soils: Insights from a $15 \mathrm{~N}$-tracing study. Soil Till. Res. 2018, 179, 38-46. [CrossRef]

49. Kane, D.A.; Snapp, S.S.; Davis, A.S. Ridge Tillage Concentrates Potentially Mineralizable Soil Nitrogen, Facilitating Maize Nitrogen Uptake. Soil Sci. Soc. Am. J. 2015, 79, 81-88. [CrossRef]

50. Cao, L.Y.; Zhang, L.; Jiang, X.J.; Su, H.F.; Shi, J.; Li, N. Effects of long-term ridge tillage on distributions of different nitrogen forms of soil water stable aggre-gates. Plant Nutr. Fertil. Sci. 2009, 15, 824-830. [CrossRef]

51. Suzuki, T.; Tokunaga, Y.; Watanabe, I. Effect of the difference of tillage operations on microbial properties of soil layers. Soil Sci. Plant Nutr. 2012, 15, 280-291. [CrossRef]

52. Doraiswamy, P.C.; McCarty, G.W.; Hunt, E.R., Jr.; Yost, R.S.; Doumbiac, M.; Franzluebbers, A.J. Modeling soil carbon sequestration in agricultural lands of Mali. Agric. Syst. 2007, 94, 63-74. [CrossRef]

53. Liu, M.X.; Wang, J.A.; Yan, P.; Liu, L.Y.; Ge, Y.Q.; Li, X.Y.; Hu, X.; Song, Y.; Wang, L. Wind tunnel simulation of ridge-tillage effects on soil erosion from cropland. Soil Till. Res. 2006, 90, 242-249. [CrossRef]

54. Zhang, P.; Chen, X.; Wei, T.; Yang, Z.; Jia, Z.; Yang, B.; Han, Q.; Ren, X. Effects of straw incorporation on the soil nutrient contents, enzyme activities, and crop yield in a semiarid region of China. Soil Till. Res. 2016, 160, 65-72. [CrossRef]

55. Li, R.; Cui, R.M.; Jia, Z.K.; Han, Q.-F.; Lu, W.T.; Hou, X.Q. Effects of different furrow-ridge mulching ways on soil moisture and water use efficiency of winter wheat. Sci. Agric. Sin. 2011, 44, 3312-3322. (In Chinese) [CrossRef]

56. Qin, S.H.; Zhang, J.L.; Wang, D.; Pu, Y.L.; Du, Q.Z. Effects of different film mulch and ridge-furrow cropping patterns on yield formation and water translocation of rainfall potato. Chin. J. Appl. Ecol. 2011, 22, 389-394. (In Chinese)

57. Liu, Y.; Zhou, X.B.; Chen, Y.H.; Qi, L.; Cui, Z.Y.; Yang, R.G.; Xu, D.L. Effects ofpre-sowing soil moisture and planting patterns on photosynthetic character-istics and yield of summer soybean. Acta Ecol. Sin. 2011, 31, 3478-3487. (In Chinese)

58. Yang, F.R.; Zhao, J.Z. Analysis of "san-long" high yield technique of soybean effect of ridge culture, deep tillage and layer fertilization on increasing soybean yield. Sci. Agric. Sin. 1995, 28, 46-51. (In Chinese)

59. Tisdall, J.M.; Hodgson, A.S. Ridge tillage in Australia: A review. Soil Till. Res. 1990, 18, 127-144. [CrossRef] 